\title{
Critical thinking ability improvement: The impact of STAD learning model in mathematic courses
}

\author{
Dodiet Enggar Wibowo ${ }^{1^{*}}$, Ali Mustadi ${ }^{1}$, Mahmudah Titi Muanifah ${ }^{2}$ \\ ${ }^{1}$ Universitas Negeri Yogyakarta, \\ ${ }^{2}$ Universitas Sarjanawiyata Tamansiswa \\ $\square$ dodietenggar.2019@student.uny.ac.id *
}

\section{Article Information \\ Submitted March 08, 2021 \\ Revised April 16, 2021 \\ Accepted April 20, 2021}

Keywords

Critical Thinking;

Mathematic Course;

STAD.

\begin{abstract}
According to some studies on school student, the application of the STAD method in some subject can improve critical thinking ability. However, according to other studies, STAD in some subject for school students cannot improve critical thinking ability. This study, hence, aims to discover the impact of the application of STAD in improving critical thinking ability, especially in mathematics course for university students. The experiment was carried out in a quasi-experimental design, especially the pretest-posttest non-equivalent group type. The findings of this study indicate that the application of STAD in mathematics learning can improve critical thinking ability. The advantages of using STAD can be seen from the increase in critical thinking ability, both abilities in the low, medium, and high categories. This study also confirms the findings of other studies that the application of cooperative and problem-based learning methods is effective in improving critical thinking ability. However, in contrast to other studies that reveal the benefits of STAD can be obtained after a long time of application ( 9 weeks -8 months), this study shows that the benefits of STAD can be obtained in a relatively short time. This occurs because the treatment in the experimental class meets the criteria set by the experts, and uses three important structures proposed by experts, too. This research, therefore, has implications for the need to use problem-based cooperative learning methods.
\end{abstract}

\section{INTRODUCTION}

Generally, in educational discourse, critical thinking ability are defined as specific thinking ability students use when they show critical thinking behavior (Nitko \& Brookhart, 2011). Furthermore, (Nitko \& Brookhart 2011) explain that this behavior is characterized by logical thinking (good reasoning), reflective (concise and clear in using reasoning), focus (has clear objectives), and is used to decide what to believe and what to do. Therefore, in critical thinking, there are mental activities in the form of induction, deduction, classification, and reasoning processes (Ariawan, 2014). If further identification is carried out, the ability to think critically would lead to skepticism, comparing, evaluating, analyzing, synthesizing, formulating various possibilities, and drawing some comprehensive conclusions (Maulana, 2017).

Other experts such as (Hashemi, 2011; Paul \& Elder, 2005) also propose a similar definition. The idea is the conclusion of the process of analyzing existing problems. In more detail, (Lloyd \& Bahr, 2010) describe five intellectual steps taken by students when they are thinking critically, including: analysis, synthesis, understanding and solving problems, concluding, and evaluating. Thus, critical thinking requires great effort to test assumptive beliefs or knowledge based on supporting evidence. On the basis of this thesis, ideally teachers need to include indicators of critical thinking ability in learning in schools, especially mathematics learning. 
Mathematics learning has a reciprocal relationship with critical thinking ability (Chukwuyenum, 2013), because both rely on logical, reflective, goal-focused thinking activities, and are used to draw correct evidence-based conclusions. So far, mathematics is considered as an important subject because theoretically it can help students develop their ability to reason, think logically, systematically, and reflectively. Therefore students with good mathematical abilities are usually able to solve problems in daily life properly based on evidence and rational reasoning. That is, the improvement of students' mathematical ability is directly proportional to critical thinking ability (Basri \& As'ari, 2018), and vice versa. Therefore, many educators empower mathematics learning to improve students' critical thinking ability. Some examples of this form of use can be found in the research of (Firdaus et al., 2015; Sumarna et al., 2016; Maričića \& Špijunović, 2015).

Mathematics learning to improve critical thinking ability is usually carried out using cooperative learning methods, such as TPS, STAD, TGT, TTW, and others. Some studies have even proven that learning mathematics to improve critical thinking ability can also be achieved with Interactive Learning Cooperative Settings (Husnaeni, 2016), ASSURE (Kristianti et al., 2017), and Realistic Mathematics Education (Palinussa, 2013). Even so, we need to admit that apparently, not all studies produce the same conclusions.

The TTW learning method, for example, does not necessarily improve critical thinking ability. According to research by (Ainin et al., 2020), in order to improve critical thinking ability, the TTW method still needs to be developed by referring to local wisdom. Likewise with the implementation of STAD. According to classroom action research by (Gustia et al., 2019; Hermawan et al., 2020) the implementation of STAD in mathematics learning can improve critical thinking ability. This improvement is marked by the increased ability of students to analyze problems, formulate various possibilities, and propose solutions based on the data they have obtained. Experimental research by (Sholikhah et al., 2019) further confirms that students' critical thinking ability increase significantly when learning is carried out using STAD, especially if learning is assisted by the use of worksheets. However, a number of other experimental studies have shown that the use of STAD is not very effective for improving critical thinking ability, even though it is used in mathematics learning.

Some of these examples are research by (Kaharudin \& Magfirah, 2018; Putra et al.. 2019; Armita \& Marsigit, 2016). According to research by (Kaharudin \& Magfirah, 2018) the STAD learning method is no more effective than the TPS learning method. Likewise, research by (Putra et al., 2019) proves the need for modification of STAD so that it can be used to improve critical thinking ability effectively, both for students with low and high academic achievement. The modification referred to is not only by adding tools as in the research of (Sholikhah et al., 2019), but refers more to a change in the concept of STAD itself. (Putra et al., 2019), in their research, introduced INSTAD as a form of development from STAD. In terms of increasing critical thinking ability and increasing academic achievement, they proved that INSTAD was more effective than guided inquiry learning and STAD itself. This development is very different from (Armita \& Marsigit, 2016), which only applies STAD in PBL settings with the intending to add and systematize problems so that students' critical thinking ability developed. Although the study revealed that STAD and TGT were both effective in increasing learning achievement and self-efficacy, they were not more effective at improving critical thinking ability. 
Based on the above background, it can be emphasized that there are problems in the form of conclusions that cannot be generalized. In previous studies, STAD for school student can improve critical thinking ability, but in several other studies, STAD is less effective for improving critical thinking ability for school student. As far as the authors have investigated, very few studies have revealed the effect of learning mathematics on critical thinking ability at the university level, especially for PGSD student. Therefore, this study intends to contribute in the form of nevelty in the discourse of the effect of learning mathematics on critical thinking ability based on testing at PGSD student. This is achieved by answering the research question: is the use of STAD in mathematics learning effective in improving university students' critical thinking ability?

\section{METHODS}

Based on the facts above, quasi-experimental research with pretest and posttest designs is needed to discover the impact of the application of STAD in improving critical thinking ability through mathematics learning. This design was chosen because it was considered appropriate for testing and measuring progress and improvement in various educational goals (Back \& Hwang, 2005). More specifically, the empowerment of quasi-experimental research in the educational setting is to test how effective new innovative learning methods are (Gopalan et al., 2020). This study designates STAD as a tested learning method because according to a number of studies above there are inconsistencies in research findings, concerning to the effectiveness of STAD to improve critical thinking ability. This means that the findings from a number of studies above cannot be generalized. Meanwhile, mathematics and critical thinking were chosen as means of testing because they have clear indicators that correlate directly with life in the real world (outside of school). Thus, the findings of this study can provide both theoretical and practical contributions.

This quantitative research uses a quasi-experimental design due to two considerations. First, the sample is not chosen randomly (referring to existing groups). Second, the treatment given during the study is intended to determine the relationship between the treatment and the specific aspects to be measured (Fraenkel et al., 2012). The relationship is a cause-effect relationship on the independent variable to the dependent variable.

More specifically, the type of quasi-experiment used in this study was the pretest-posttest non-equivalent group type. In this study, the treatment given was cooperative learning (type STAD), while the aspect measured was critical thinking ability. Therefore, the assumption is use of STAD (independent variable) can affect critical thinking ability (dependent variable). An overview of this type of quasi-experiment is illustrated by (Cohen et al., 2007) in Table 1.

Table 1. Research Design

\begin{tabular}{lccc}
\hline Testing group & Pretest & Treatment & Posttest \\
\hline Experiment & $\mathrm{O}_{1}$ & $\checkmark$ & $\mathrm{O}_{2}$ \\
Control & $\mathrm{O}_{3}$ & - & $\mathrm{O}_{4}$ \\
\hline
\end{tabular}

Information:

O $\quad$ : pretest and posttest scores of the control group and the experimental group

$\checkmark \quad$ : treatment (application of STAD in mathematics learning)

- $\quad$ : ordinary learning (without the application of STAD) 


\section{Materials and instrument}

The subjects in this study were PGSD students in class $2 \mathrm{C}$ and $2 \mathrm{G}$ at Sarjanawiyata Tamansiswa University (the academic year 2020/2021). This study used a population sample so that all 45 students from the $2 \mathrm{C}$ class (consisting of 9 males and 36 females) and all 45 students from the $2 \mathrm{G}$ class (consisting of 11 males and 34 females) were involved as research subjects. This decision was made because the critical thinking abilities of the two groups did not show a significant difference. Class $2 \mathrm{C}$, in this study, was treated as an experimental group. In contrast, class $2 \mathrm{G}$ was treated as a control group.

Table 2. Research instruments

\begin{tabular}{lccc}
\hline \multirow{2}{*}{ Indicators } & \multicolumn{2}{c}{ Number of statement items } & Total \\
\cline { 2 - 3 } number
\end{tabular}

As the type of pretest-posttest, this study uses worksheets critical thinking ability test, which is given to students at the beginning and end of the study. The instrument given to students at the end of the lesson (posttest phase) is in the form of a descriptive test. The instrument was developed from the aspects of critical thinking ability (Table 2) as stated by (Paul \& Elder, 2005).

To ensure the quality of the instruments, content validation was carried out. This validation was done by submitting an assessment to two experts at the Universitas Sarjanawiyata Taman Siswa. The assessment examines the instrument according to a number of criteria, namely: (1) the suitability of the items with the assessment indicators, (2) clear boundaries on each test item, (3) conceptually, the questions are asked correctly, (4) the information has been conveyed clearly in the questions posed, (5) the formulation of the questions uses simple language, (6) questions is quite communicative, (7) the questions asked do not lead to multiple interpretations, (8) the test items use good and correct Indonesian. Content validation was needed to get experts' suggestions for improvement of instrument quality (based on the experts' recommendations).

The content-validated instruments were then empirically validated. Empirical validation is needed to ensure the validity and reliability of the critical thinking ability instrument. Empirical validation was carried out on 59 randomly selected PGSD students. The data obtained for validation purposes were analyzed using the product-moment correlation technique (to determine validity) and Cronbach's alpha (to determine reliability).

\section{Data analysis}

The collected data were analyzed using two-way ANOVA because the two-way ANOVA was able to reveal the difference in the mean of each group. Apart from these considerations, the ANOVA technique was selected because the data in this study met two requirements, namely 
homogeneous and normally distributed (Hadi, 1997). Using these analytical techniques, this research could determine whether the hypothesis is accepted or rejected. If Ho is not accepted, which means there is an improvement in students' critical thinking ability, the testing would be continued to the Tukey's range test. If $H o$ is accepted, which means there is no improvement in students' critical thinking ability, no further tests are conducted.

Table 3. The Criteria of Research Results

\begin{tabular}{cc}
\hline Students' critical thinking ability & Value Range \\
\hline High & $x \geq \bar{x}+\sigma$ \\
Medium & $\bar{x}-\sigma<x<\bar{x}+\sigma$ \\
Low & $x \leq \bar{x}-\sigma$ \\
\hline
\end{tabular}

Information:

$x \quad=$ score

$\bar{x} \quad=$ average score

$\sigma \quad=$ standard deviation score

Data obtained from the student's critical thinking ability worksheet test were processed using descriptive and inferential statistics by using SPSS version 22. Data processing begins with homogeneity and normality testing, then proceeds to calculate the N-gain to determine the level of critical thinking ability (Meltzer, 2002). The hypothesis was tested through a oneway MANOVA test (level of significance: $5 \%$ ). To determine the level of critical thinking ability, the range in Table 3 was applied.

\section{RESULTS AND DISCUSSION}

Analysis of mathematical critical thinking ability improvement data obtained from the results of N-Gain is grouped based on the level of critical thinking ability of students. It starts by classifying students based on the level of their critical thinking ability (Table 4). Based on Table 4, both students from the experiment group and control group, mostly have enough critical thinking ability ability. However, students from the experimental group had better critical thinking ability (six students were in the high category). Furthermore, N-gain grouping was conducted based on the level of critical thinking ability and is statistically presented in Table 5.

Table 4. Students' Critical Thinking Ability

\begin{tabular}{lllll}
\hline \multirow{2}{*}{\begin{tabular}{l} 
Levels of $\begin{array}{c}\text { students } \\
\text { critical thinking ability }\end{array}$ \\
\cline { 2 - 5 }
\end{tabular}} & $\begin{array}{l}\text { Learning } \\
\text { STAD }\end{array}$ & \multicolumn{2}{l}{ Without STAD (conventional) } \\
\hline high & 6 & $13 \%$ & $\mathbf{n}$ & $\mathbf{( \% )}$ \\
medium & 31 & $69 \%$ & 3 & $9 \%$ \\
low & 8 & $18 \%$ & 7 & $76 \%$ \\
Amount & $\mathbf{4 5}$ & $\mathbf{1 0 0 \%}$ & $\mathbf{4 5}$ & $16 \%$ \\
\hline
\end{tabular}


Table 5. Improvement of Critical Thinking Ability

\begin{tabular}{lcll}
\hline \multirow{2}{*}{ Curiosity level } & \multirow{2}{*}{ Statistics } & Learning & \\
\cline { 3 - 4 } high & $n$ & 6 & Without STAD \\
\hline \multirow{3}{*}{ medium } & $\bar{x}$ & 0,659 & 4 \\
& $s$ & 0,05 & 0,253 \\
& $n$ & 31 & 0,11 \\
\hline \multirow{3}{*}{ low } & $\bar{x}$ & 0,575 & 34 \\
& $s$ & 0,16 & 0,349 \\
& $n$ & 8 & 0,10 \\
\hline
\end{tabular}

In table 5, it can be seen the improvement of students' mathematical critical thinking ability. The mean enhancement in students' mathematical critical thinking ability (high, medium, low) in the experimental group is better than the control group. Hence, the following hypotheses are presented for testing interests: (1) There is a difference in students' critical thinking ability through the use of STAD in mathematics courses; (2) There is a difference in students' critical thinking ability through the use of STAD in mathematics courses or not; (3) There is a difference in the improvement of students' critical thinking ability through the use of STAD in mathematics subjects; (4)There is a difference in the improvement of students' critical thinking ability through the use of STAD (high, medium, low) in mathematics subjects or not. By using SPSS 22, the results of the hypotheses testing are presented in Table 6.

Table 6. The Summary of Hypothesis Testing (1, 2, and 3)

\begin{tabular}{|c|c|c|c|}
\hline $\begin{array}{l}\text { Mathematical } \\
\text { thinking ability }\end{array}$ & critical & Test results & Conclusion \\
\hline high & & Sig. $(2$-tailed $)=0,000 \leq 0,05$ & Hypothesis accepted \\
\hline enough & & Sig. $(2$-tailed $)=0,000 \leq 0,05$ & Hypothesis accepted \\
\hline low & & Sig. $(2$-tailed $)=0,000 \leq 0,05$ & Hypothesis accepted \\
\hline
\end{tabular}

Table 7. ANOVA Test Results

\begin{tabular}{llllll}
\hline & Sum of squares & df & Mean square & F & Sig. \\
\hline Between Groups & .003 & 2 & .002 & .050 & .952 \\
Within Groups & 2.287 & 72 & .032 & & \\
Total & 2.290 & 74 & & & \\
\hline
\end{tabular}

Based on Table 6, it can be concluded that on average, the enhancement of student ability to think critically in STAD group is better than students who get conventional learning, both in high, medium, and low curiosity category. Furthermore, hypothesis 4 was tested by using one-way ANOVA. The results are presented in Table 7. Based on table 7, it can be concluded that $\mathrm{H}_{0}$ is accepted $\left(\mathrm{H}_{1}\right.$ is rejected). So it can be said that on average, there is no difference in the enhancement of students' critical thinking ability from the level of curiosity (high, medium, low).

\section{Discussion}

The improvement of critical thinking ability in the experiment group is higher than in the control group. This indicates that the use of the STAD learning model is effective in increasing students' mathematical critical thinking ability. This finding confirms various previous research. A study by (Zetriuslita \& Ariawan, 2017) concludes that the use of teaching materials based on problem-based learning in calculus subjects can improve students' 
critical thinking ability. In line with those research conclusions, (Pangestuti, 2017) study shows that Remap-STAD can improve students' critical thinking ability. This is known from the results of the final test cycle analysis, which is showing an improvement in scores from the first cycle to the second cycle. The average critical thinking score of the first cycle was 65.0, while in the second cycle was 72.2. Still, the results study by (Din, 2020) reveals that students have a very positive attitude towards critical thinking but their level of critical thinking and ability to reflect critical thinking in their critical reading ability do not match their attitude to critical thinking.

However, other studies deserve mutual attention, in connection with this research. In that study, it was emphasized that the treatment would have a significant impact if the treatment was carried out for a long time. This means that short-term treatment as carried out in this study rarely has a significant impact. This is also the novelty of this research. A number of these studies are paper by (Hong \& Yu, 2017), which reveals that after receiving 19 casebased learning lectures for 8 months, both groups of students significantly improved their critical thinking ability, and a study by $\mathrm{Li}$ et al. (2019), which found that there were no statistically significant differences between the two groups ( $\mathrm{P}>0.05)$. After nine weeks, the critical thinking ability of the experimental group was significantly higher than the control group $(\mathrm{P}<0.05)$. Three-time points obtained had statistically significant control and experimental differences $(\mathrm{P}<0.05)$.

The above case occurs because the developed learning model (like STAD) is at the highest application level of instruction. Critical thinking learning instructions are designed into 8 steps consisting of triggering activities, identifying problems, investigating related data, discussing findings, evaluating findings, creating solutions, presenting solutions, and reflecting learning outcomes (Vong \& Kaewurai, 2017). Moreover, STAD cooperative learning in the experimental group has met the characteristics of STAD cooperative learning itself, as stated by (Khan \& Inamullah, 2011), namely collaboration between groups to achieve goals and the assessment process is carried out continuously or when the learning process is taking place (on-going assessment). These kinds of learning methods prevent students from misunderstanding, which so far has often been caused by teacher-centered learning (Miftakhuddin et al., 2019).

Apart from the fact that STAD in this study was conducted by referring to the STAD standards above, this study also used the harmonization of three important structures as stated by (Roseth et al., 2008). These three are task, goal, and reinforcement. Assignment refers to the suitability of the tasks given during learning. Purpose refers to the knowledge or ability students will have after the learning process takes place. As for strengthening, it refers to giving gifts to each group after completing the tasks given to them as well as on-going assessment. Thus, the importance of critical thinking ability are to help student to: think rationally in order to making decissions, able to make conclusion based on alternative logical thinking, and able to examine and disregard various complex problems. However, to support the three important structures as stated by (Roseth et al., 2008), teachers would need to upgrade their self-efficacy. It is because the self-efficacy is a crucial variable pedagogical competence as it could determine how teachers managed their classroom in order to attain maximum students' achievement (Rahayu et al., 2019).

This study, in the end, confirms the research of (Sumarna et al., 2016) who conducted experimentation on PGSD students to determine the increase in critical thinking ability. Both 
this study and the research of (Sumarna et al., 2016), concluded that the use of cooperative learning in mathematics courses tends to be effective in improving critical thinking ability for PGSD students. Likewise, the research of (Azizahwati \& Ernidawati, 2019) which uses the STAD cooperative learning model for students in other study programs. It is different from the two studies, this research provide further classification by dividing the critical thinking improvement based on the initial level of student university critical thinking.

\section{CONCLUSIONS}

Based on the concise analysis above, it can be concluded that the application of STAD in mathematic learning can improve critical thinking ability. The improvement is evidenced by the results, which state that 27 students begin to think critically. This is indicated by the achievement of indicators: clarity, accuracy, accuracy, relevance, the logic of thinking, breadth, depth thinking, honesty, completeness of information, and the implications of the proposed solutions. However, not all students who begin to think critically can make implications appropriately. Only 18 students or $13.33 \%$ were able to make the implications properly. Based on these findings, STAD should be implemented based on problems, and meet the criteria set experts and use three important structures proposed by another experts as stated in previous section of this paper.

This study has proven that the use of STAD in mathematics learning to PGSD students can improve their critical thinking ability. However, as a research with an experimental design, this research can only to reveal the cause and effect. This study was unable to reveal the relationship between STAD and critical thinking ability. To overcome the limitations of this study, it is recommended to further researchers to conduct research in a correlational design.

\section{AUTHOR CONTRIBUTIONS STATEMENT}

DEW worked as the main drafter in this research. data collection and instrument design assisted by AM and TMM.

\section{REFERENCES}

Ainin, Q., Mulyono, M., \& Syahputra, E. (2020). Development of cooperative learning Think-Talk-Write (TTW) models based on Batak culture to improve students' mathematical critical thinking ablity. Al-Jabar: Jurnal Pendidikan Matematika, 11(2), 287-298.

Ariawan, I. P. W. (2014). Pengembangan LKM multi representasi berbantuan geogebra untuk meningkatkan kemampuan berpikir kritis mahasiswa. Jurnal Pendidikan Indonesia, 3(1), 359-371.

Armita, U. Y., \& Marsigit, M. (2016). Keefektifan PBL setting STAD dan TGT ditinjau dari prestasi, berpikir kritis, dan self-efficacy. Jurnal Pendidikan Matematika Dan Sains, 4(1), 1-11.

Azizahwati, A., \& Ernidawati, E. (2019). Implementation of STAD cooperative learning to improve students' learning outcomes. Proceeding of the SS9 \& 3rd URICES, 1, 491495.

Back, S. G., \& Hwang, E. H. (2005). A quasi-experimental research on the educational value of performance assessment. Asia Pacific Education Review, 6(2), 179-190. 
Basri, H., \& As'ari, A. R. (2018). Improving the critical thinking ability of students to solve mathematical task. JIPM (Jurnal Ilmiah Pendidikan Matematika), 7(1), 13-21.

Chukwuyenum, A. N. (2013). Impact of critical thinking on performance in mathematics among senior secondary school students in Lagos state. IOSR Journal of Research \& Method in Education (IOSRJRME), 3(5), 18-25.

Cohen, L., Manion, L., \& Morrison, K. (2007). Research methods in education (6th ed.). Routledge.

Din, M. (2020). Evaluating university students' critical thinking ability as reflected in their critical reading skill: A study at bachelor level in Pakistan. Thinking Skills and Creativity, 35(September 2019), 100627.

Firdaus, F., Kailani, I., Bakar, M. N. Bin, \& Bakry, B. (2015). Developing critical thinking skills of students in mathematics learning. Journal of Education and Learning (EduLearn), 9(3), 226-236.

Fraenkel, J. R., Wallen, N. E., \& Hyun, H. H. (2012). How to design and evaluate research in education.

Gopalan, M., Rosinger, K., \& Ahn, J. Bin. (2020). Use of quasi-experimental research designs in education research: Growth, promise, and challenges. Review of Research in Education, 44(1), 218-243.

Gustia, D. E., Mawardi, M., \& Astuti, S. (2019). Implementation of STAD learning models to improve 5th students' critical thinking skills and mathematics learning outcomes. Jurnal Daya Matematis, 7(1), 102-112.

Hadi, S. (1997). Metodoogi penelitian. UGM Press.

Hashemi, S. A. (2011). The use of critical thinking in social science textbooks of high school: A field study of Fars province in Iran. International Journal of Instruction, 4(1), 63-78.

Hermawan, C. M., Rosfiani, O., Suheti, \& Susanti, S. F. (2020). STAD type cooperative learning model: An action in learning mathematics. International Journal of Scientific and Technology Research, 9(4), 1871-1875.

Hong, S., \& Yu, P. (2017). Comparison of the effectiveness of two styles of case-based learning implemented in lectures for developing nursing students' critical thinking ability: A randomized controlled trial. International Journal of Nursing Studies, 68, 1624.

Husnaeni. (2016). The enhancement of mathematical critical thinking ability of aliyah madrasah student model by using interactive learning setting cooperative model. Journal of Education and Practice, 7(8), 159-164.

Kaharudin, A., \& Magfirah, I. (2018). Perbandingan keefektifan model think pair share dan student team achievement divisions pada pembelajaran matematika SD Negeri di kabupaten Soppeng. Jurnal Taman Cendikia, 2(2), 223-230.

Khan, G. N., \& Inamullah, H. M. (2011). Effect of student's team achievement division (STAD) on academic achievement of students. Asian Social Science, 7(12), 211-215.

Kristianti, Y., Prabawanto, S., \& Suhendra, S. (2017). Critical thinking skills of students through mathematics learning with ASSURE model assisted by software autograph. 
Journal of Physics: Conference Series, 895(1).

Lloyd, M., \& Bahr, N. (2010). Thinking critically about critical thinking in higher education. International Journal for the Scholarship of Teaching and Learning, 4(2), 0-16.

Maričića, S., \& Špijunović, K. (2015). Developing critical thinking in elementary mathematics education through a suitable selection of content and overall student performance. Procedia - Social and Behavioral Sciences, 180, 653-659.

Maulana. (2017). Kemampuan dasar matematika dan pengembangan kemampuan berpikir kritis-kreatif. UPI Press.

Meltzer, D. E. (2002). The relationship between mathematics preparation and conceptual learning gains in physics: A possible "hidden variable" in diagnostic pretest scores. American journal of physics, 70(12), 1259-1268.

Miftakhuddin, A. M., \& Zulfiati, H. M. (2019). Misconceptions between Social Studies and Social Sciences among Pre-Service Elementary Teachers. International Journal of Education, 12(1), 16-25.

Nitko, A. J., \& Brookhart, S. M. (2011). Educational assessment of students (6th ed.). Pearson Education.

Palinussa, A. L. (2013). Students' critical mathematical thinking skills and character: Experiments for junior high school students through realistic mathematics education culture-based. Journal on Mathematics Education, 4(1), 75-94.

Pangestuti, A. A. (2017). Penerapan model pembelajaran biologi berbasis remap-stad untuk meningkatkan kemampuan berpikir kritis dan hasil belajar kognitif mahasiswa ikip budi utomo malang. Edubiotik: Jurnal Pendidikan, Biologi Dan Terapan, 2(1), 13-22.

Paul, R., \& Elder, L. (2005). The miniature guide to critical thinking. The Foundation of Critical Thinking.

Putra, B. K. B., Prayitno, B. A., \& Maridi. (2019). Effectiveness of INSTAD teaching model in improving students' critical thinking with high and low level academic achievement. Advances in Social Science, Education and Humanities Research (ASSEHR), 330(Iceri 2018), 350-355.

Rahayu, L. P., Sartono, E. K. E., \& Miftakhuddin, M. (2019). The Self-efficacy of Primary School Teachers in Teaching Mathematics: A Comparative Research on Teacher Training Program Products. Mimbar Sekolah Dasar, 6(1), 68-78.

Roseth, C. J., Johnson, D. W., \& Johnson, R. T. (2008). Promoting early adolescents' achievement and peer relationships: The effects of cooperative, competitive, and individualistic goal structures. Psychological Bulletin, 134(2), 223-246.

Sholikhah, F., Raharjo, T. J., \& Suhandini, P. (2019). The effect of the STAD learning model aided by students worksheet to improve critical thinking skills of students. Journal of Primary Education, 11(1), 1-6.

Sumarna, N., Wahyudin, \& Herman, T. (2016). The increase of critical thinking skills through matematical investigation approach. Journal of Physics: Conference Series, 755(1).

Vong, S. A., \& Kaewurai, W. (2017). Instructional model development to enhance critical thinking and critical thinking teaching ability of trainee students at regional teaching 
training center in Takeo province, Cambodia. Kasetsart Journal of Social Sciences, $38(1), 88-95$.

Zetriuslita, \& Ariawan, R. (2017). The effectiveness of problem-based learning materials in improving students mathematical critical thinking skills: A study in calculus course. 6th International Conference on Education, Humanities and Social, Sciences Studies (EHSSS-17). 